\title{
Panchamahabhuta Siddhanta: Application of Panchbhautik Chikitsa in the management of Cervical Torticollis
}

\author{
Case Report
}

\section{Megha R Jagtap ${ }^{1^{*}}$}

\author{
1. Associate Professor, Department of Sharir Kriya
}

M.S. Ayurved Medical College and Research Centre, Gondia.

\begin{abstract}
Cervical Torticollis or dystonia is a painful condition of cervical muscles. This disease has no cure with modern medicines. The present case report is based on clinical success story of a patient diagnosed with cervical torticollis by modern science. As the symptoms are suggestive of vataj vyadhi and involment of Kandara, patient was successfully treated with ayurvedic medicines with application of Panchbhautik Siddhanta.
\end{abstract}

Key Words: Snayugat Vata, Panchbhautik Chikitsa, Suvarna Makshik Bhasma, Cervical Torticollis, Suvarnagairik.

\section{Introduction:-}

Cervical torticollis is a painful condition in which neck muscles contract involuntarily causing twisting of head to one side. The pain is excruciating in nature. This is a rare disorder that can occur at any age, but most often occurs in middle aged people. Women are more prone than men. There is no cure for cervical torticollis in modern science (1). Risk factors for torticollis include a family history of the disorder, congenital abnormalities of the cervical spine, taking drugs that predispose to muscular spasm, and trauma.

In Ayurveda there is no direct reference regarding cervical torticollis and its management. But one may compare signs and symptons of torticollis with snayugat vata. Being vataj disorder there is rigidity, severe pain, tremors, spasm in affected snayu or kandara (ligament) (2). In Ayurveda Kandara has origin of raktadhatu and sneh (3). Raktadhatu (blood) is cardinal ingredient in the composition of kandara (4). Kandara are predominance of prithvi mahabhuta. Out of chaturastra kandara one has origin from penis and terminates at cervical region (5). Any pathological factor affecting raktadhatu, vatadosha and pittadosha or prithvi mahabhuta may give manifestations of weakness of kandara or muscle. Keeping all these factors in view, patient was successfully treated with Ayurvedic medicines.

\section{Case Report: -}

A moderately built, male aged 34 years, weighing $59 \mathrm{~kg}$ and height 5' 8" came with chief complaint of excruciating pain and severe stiffness in cervical region since 15 days. Along with these complaints, erection of

\section{*Corresponding Author:}

\section{Megha R Jagtap}

Associate Professor,

Department of Sharir Kriya

M.S. Ayurved Medical College and Research Centre,

Gondia

Email ID:- vd.jagtapmegha@gmail.com penis, urge to micturate immediately after attack of pain, and sudden onset of blackouts were the associated symptoms. MRI of cervical spine was suggestive of cervical torticollis. Patient had undergone several years of allopathy treatment with painkiller, muscle relaxant drugs and physiotherapy. But patient was not cured.

Patient used to observe fast 3 days a week and was habitual of skipping meals on and off. There was no other significant history of other medical disorders.

Patient was examined thoroughly and was prescribed following medicines by applying Panchmahabhuta siddhanta. Strict compliance of prescribed drugs with healthy food habits was also advised. Patient was asked to stop all the past medication he was taking.

Keeping Ayurveda Panchabhautik view in mind patient was treated with:-

- Suvarnamikshik bhasma (6) $60 \mathrm{mg}$ twice daily with goghrut, 1 table spoon, after meal.

- Suvarnagairik bhasma (7) $120 \mathrm{mg}$ twice daily before meal with water.

\section{Observations and Result:}

Patient came with severe symptom of dystonia and severe pain. Medication was started and apart from this he was insisted for healthy food habits. Assessment was done on the basis of severity and frequency of episodes of cervical stiffness and pain. Duration of episode was also assessed. Assessment was done before treatment and every $10^{\text {th }}$ day of treatment schedule.

On $10^{\text {th }}$ day of treatment severity of pain and cervical stiffness turn from severe to moderate. Duration of episode came down from 45 minutes to $20-30 \mathrm{~min} /$ episode. Frequency of episode turn down from 5 times/ wk to 3 times/wk. all the associated symptoms were reduced to mild in first assessment. But patient complaint of beltching. So pathyodi kwath was added; 20 $\mathrm{ml}$ twice a day with water to take care of vitiated pittadosha and raktadhatu. On $21^{\text {st }}$ day, complete reduction of cervical pain and stiffness was noted. To avoid relapse and provide strength to mamsa and rakta dhatu, rasayan chikitsa with shatavari and ashwagandha 
churna were added for 2 months.

Only oral medication selected on the basis of panchhbhutik siddhanta and nidan parivarjan helped him in his improvement.

\section{Discussion:}

In cervical torticollis, symoptoms are suggestive of vataj disorder and affected factor is kandara/snayu (ligament), the line of treatment is snehan, (nourishment) and balya. Kandara is a factor predominant in prithvi mahabhuta and rakta (blood) is a cardinal ingradient in composition of it. Hence nourishment of kandara with prithvi predominating drug and raktaprasadan was main objective of treatment. Patient was used to skip meals and other unhealthy food habits which ultimately resulted in vitiation of vata dosha, pitta dosha and inturn rakta prokopa.

Keeping all this in view, suvarnamakshik, suvaranagairik bhasam were administered along with ghrut. Both of them are prithvimahabhuta predominant and have blood purifying properties. They might have increased strength of raktadhatu qualitatively and ultimately strengthen kandara of cervical region. Suvarnagairik has taken care of vitiated pittadosha and also strengthen raktadhatu. Both of them have enhanced raktadhatu qualitatively. Ghrut was selected as anupana which has taken care of vitiated vatadosha and pittadosha.

\section{Conclusion:-}

The classical Ayurvedic therapy is based on various siddhanta. This case is successfully treated with Panchbhautik siddhanta. This concept involves interpretation of scientific knowledge, and disease management approach on the background of panchmahabhuta theory. While treating patients, Ayureveda does not emphasize on labeling diseases but given due importance to causative factors, samprati etc and analysis on the basis of different siddhanta. This help to treat many complicated medical conditions which has no cure with modern medicines.

For most complicated conditions which have just symptomatic management by allopathy, have great hopes with Ayurvedic treatment for its cure by applying Panchbhautik siddhanta. The present case is successfully treated by Ayurveda and has given encouraging results for future practice. Using Panchabhauthik Chikitsa Siddhanta, vaidyaraj Datarshastri has treated jirnakasa very successfully (8). Panchabhauthik Chikitsa Siddhanta is one of the great siddhanta of Ayurveda which may help every Ayurveda practitioner to accept diagnostic and therapeutic challenges.

\section{References:-}

1. http//www.ninds.nih.org.gov / disorders / dyston'as (as cited 9 August 2014, 7.15 p.m.)

2. Shrisatyanarayan Sharsti. The Caraka Samhita. Chikitsasthan. Vatvyadhi Chikitsa Adhyay 28/20-23. $20^{\text {th }}$ edition. Varanasi; Chaukhamba Bharati Acade$m y ; 1994.780-783$ p.

3. Priyavrat Sharma. Sushrut Samhita, sharirsthan. Garbhvyakaran shariradhyay 4/29. Reprinted edition. Varanasi; Chaukhamba Surbharati Prakashan; 2010. 54p.

4. Shrisatyanarayan Shastri. The Caraka Samhita. chikitsasthan. Grahanidoshchikitsa Adyay 15/17. $20^{\text {th }}$ edition. Varanasi; Chaukhamba Bharati Academy; 1994. $456 \mathrm{p}$. 